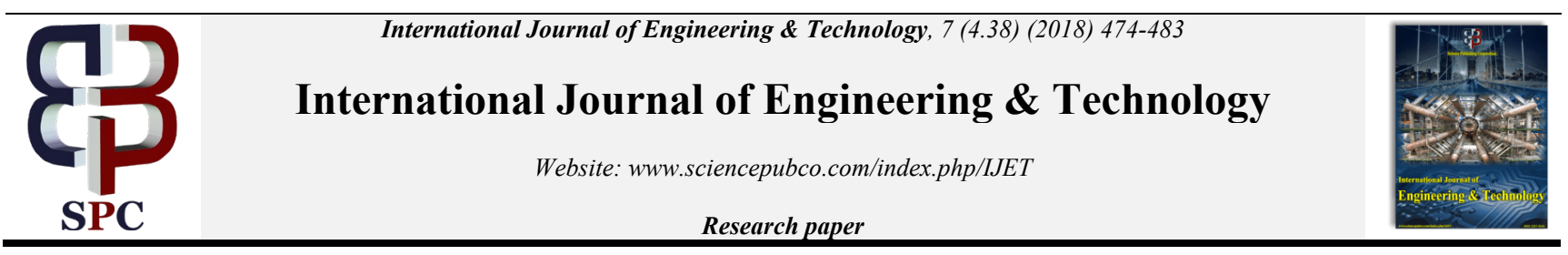

\title{
The Evolution of Polish War Feature Films (1940-1980)
}

\author{
Elena Shatova ${ }^{1 *}$ \\ ${ }^{\text {I}}$ Pushkin Leningrad State University, Petersburg highway, 10, Pushkin, St. Petersburg, 196605, Russia \\ *Corresponding author E-mail: shatova.e1@bk.ru
}

\begin{abstract}
Introduction. The relevance of this study is explained by the rapid social and political homogenization of Europe; the "disclosure" of many documents indicative of sociocultural changes in Eastern Europe; an increasing chronological gap between the research subject and its researcher that enables to use scientific verification methods instead of ideologically "correct" paradigms.

Methods. The methodological basis of this article is the principles of systematicity and objectivity. While conducting this research, the author also used genetic, typological, comparative, hermeneutic and semiotic methods.

Results. Throughout the postwar history, Polish filmmakers were bringing stories about World War II to the silver screen. The concept of a war feature film also changed depending on the postwar development of Poland.

Discussion. The necessary conditions for studying the evolution of Polish war feature films based on systematicity and objectivity are as follows: the analysis of the Polish sociocultural postwar development (periodization with distinguishing essential characteristics of each period); the determination of main trends in the development of spiritual culture as a part of sociocultural processes; the analysis of the state-party politics in the sphere of culture, art and cinema.

Conclusion. Throughout the postwar development, Polish filmmakers were addressing the topic of war. Their attitude to war changed depending on the country's socio-cultural development and the evolution of its spiritual culture. For instance, war feature films were the most prominent trend in the development of the Polish cinema in the second half of the 1940s and the first half of the 1950s. Between 1956 and 1960, the Polish Film School was established and was characterized by a high interest in war-related films (alongside other topics and problems represented in the cinema of that time). In the 1970s, war feature films were still relevant but gave way to flicks about modern times. In the 1980s, this topic "withdrew into the shadows" not only in cinematography but also in other artistic spheres. It was mostly used in films to better interpret other topics.
\end{abstract}

Keywords: Cultural dynamics; Culture and society; Polish Film School; Semiotics of culture; War feature film.

\section{Introduction}

After World War II, Poland experienced profound changes in all spheres of life, including spiritual culture. Since the end of the $20^{\text {th }}$ century (after 1989), many aspects of the country's culture were reinterpreted. Scholars revealed new and previously unknown documents, authors conducted studies based on various methodological bases and analyzed the events, processes and phenomena that took place in the People's Republic of Poland from different perspectives. The research of the Polish postwar culture became quite relevant.

Cinema is an integral part of social spirituality, the evolution of which goes alongside the sociocultural development of society. In previous decades, Polish films were shown in Russian cinemas and broadcasted on television. However, modern audience, especially the younger generation, hardly knows anything about the Polish cinema. Currently, it is hard to watch the flicks created by Polish filmmakers on a wide screen. Due to the above-mentioned circumstances, the research relevance is explained by the need to expand the concept of the Polish culture as exemplified by the development of its national cinema and feature films, in particular, war feature films.

The study objective is to identify and interpret the evolution of Polish war feature films in the context of sociocultural processes determining the development of the People's Republic of Poland. To attain this end, the author of the article fulfills the following tasks: distinguishes stages of the country's postwar development; analyzes the Polish state policy in the field of cinematography; enlists war feature films; reveals the dynamics of the cinematographic concept of war and its eidological characteristics.

The empirical base of this research is formed by war feature films, documents, essays, critical articles and epistolary materials. Its theoretical basis is represented by a broad corpus of the scientific literature (Soviet and Russian, as well as Polish and English), the interdisciplinary character of which can be demonstrated by the following classification: 1. Studies of sociocultural processes in the People's Republic of Poland - [1-13]; 2. Articles on the postwar spiritual culture of Poland - [14- 17]; 3. Academic papers of cinema theorists and film historians - [18-21]; 4. Research on the evolution of war feature films - [21-26].

While considering the evolution of war feature films in the People's Republic of Poland, the author of the article has adhered to the periodization of the sociocultural development of postwar Poland introduced by the collaborative writing team of V.K. Volkov, S.M. Stetskevich, A.M. Orekhov and I.V. Pimenova [27]. Thus, the evolution of war feature films the following four periods is considered: 1. the second half of the 1940s and the first half of the $1950 \mathrm{~s}$ - the establishment of people power and transition to the Stalinist model of socialism; 2. 1956-1960s - from the crisis of 
1956 to the crisis of $1970 ; 3$. the 1970 s - the development of accelerated economy and the formation of opposition; 4 . the $1980 \mathrm{~s}-$ an economic and political crisis in the country.

\section{Research Methods}

The author of the article carried out the socio-humanitarian study of trends in cultural dynamics (the relations between culture and society, individual and social enculturation, etc.) based on the principles of systematicity and objectivity, using comparative, genetic, typological, semiotic and hermeneutic methods. The validity of this methodological basis can be explained by a thorough definition and detailed study of the corresponding theoretical foundations. In this section of the article, the author dwells on the most valuable methods of scientific research.

The scientific study conducted by the collaborative writing team headed by V.K. Volkov [27] thoroughly considered the political history, economic development and evolution of spiritual life in Poland. These authors developed the periodization of the sociocultural postwar development of Poland. The value of their academic research is in the abundant use of statistical materials. Their paper paid much attention to the decisions of political forums but analyzes their practice in a laconic manner. This collective research [15] is valuable from an empirical viewpoint since it presents a large number of opinions of political and Catholic figures, the Polish society and intelligentsia. The polemical study [14] contained information (appeals, policy papers, statistics, etc.) on the formation of the Polish opposition movement - Solidarność. This paper is of a particular interest due to its narrative form, discussion and subjective assessments of the events happening in the country. Czubiński [16] traced the connection between the political and spiritual life of Poland and developed an original periodization of the spiritual and ideological evolution of society. The value of this publication is in its rich empirical materials crucial for studying the postwar life of Poland.

The main problem addressed by Zwierchowski [22] is the official artistic method of the postwar Polish cinematography. Using extensive empirical materials, the author analyzed the role of censorship in the Polish cinema, the activities of various departments and institutions governing the development of ideological, spiritual and artistic spheres. The publication is also characterized by the author's disputes with other researchers. Płażewski's paper [21] represents a study of the Polish cinema from its formation to the turn of the $20^{\text {th }}$ and $21^{\text {st }}$ centuries. The narrative features a detailed analysis of many literary and epistolary works. The opinion expressed by the author is supported by arguments. This book is also valuable since it considers the activities of filmmakers and their results as a part of the whole sociocultural process (including the past). Madej [23] thoroughly analyzed the formation of socialist realism in the Polish cinema, which had been determining not only the development of cinematography but also the entire spiritual culture for several decades.

Yurenev's research [28] considers the evolution of the Polish cinema within the boundaries of the cinematography of other socialist countries. The author suggested his own interpretation of the Polish Film School. Rubanova [25] emphasized the thematic diversity of the Polish postwar cinema and its dominant attention to the topic of war. Sobolev $[29,30]$ defined the following characteristics of the films of the first postwar decades: a certain similarity to documentary films, reliance on literary works, the dominance of military themes, etc. However, his studies did not analyze the state's cultural policy, and he did not mention any censorship in the Polish culture and cinematography. Sumenov's monograph [31] is concerned with Soviet-Polish war films. The author provided researchers with extensive epistolary materials but did not try to trace the relationship between films and their sociocultural context.

\section{Results}

The development of the Polish cinema in the first postwar decades was based on the achievements of the pre-war period and represented both its logical follow-up and a new stage. The pre-war cinematography of Poland was regarded as "commercial" [32, p. 199], "provincial" [33, p. 8] and "cheap entertainment" [24, p. 144]. The postwar changes taking place in the country were also expressed in the national cinema.

The events of World War II were still alive in the memories of the Polish people. Many filmmakers also witnessed war atrocities of the Soviet and German occupation regimes, took part in military operations and became victims of concentration camps. Directors of the first postwar films "showed the war, not as a historical concept but their personal and timeless story" [29, p. 106]. In the wartime, Aleksander Ford, Leonard Buczkowski and Stanislaw Wohl were combat camera operators. Their documentary evidence of the war events had been used in later war feature films for a long time. Jakubowska and her colleagues working on the motion picture "Ostatni etap" ("The Last Stage") [34] were prisoners of Auschwitz. Andrzej Wajda joined the Armia Krajowa (AK) and was a member of the so-called Radom Squadron.

The Polish cinema of the early postwar period "could not be called universally oriented" [24, p. 146]. However, war feature films had been very popular among filmmakers in the following years. Motion pictures created in the wartime (mostly documentaries) encouraged the audience to stand up to the enemy and resist fascism; they depicted fortitude and invincibility. Cinematographers comprehended the fate of the Polish people from different viewpoints and expressed it using different artistic methods. There is no other national cinema that expressed an anti-fascist rebuff with the same vehemence.

The dominance of war feature films during this period can be explained by the following reasons: a short chronological distance between war- and postwar-time, personal experiences of filmmakers, and regulatory rules (censorship). The creativity of cinematographers was initially under control, and they were forced to obey the regulations issued by various departments [35]. Their prescriptions primarily concerned the themes of films: "the state influenced the subject of a motion picture" and "the cinema influencing masses could not let them forget war tragedies" [23, p. 55]. As a result, "the struggle for unified socialist consciousness" started in the Polish cinema, which led to more severe regulatory rules [16, pp. 308-309]. Ford who participated in the Congress of Filmmakers in Wisła (1949) recalled, "All of them tirelessly spoke that it was impossible to unify people without unifying their ideas. In this case, war is a theme understandable to all without exception" [26, p. 7].

The Congress of Filmmakers in Wisła launched a new stage in the development of the Polish cinema called "the domination of socialist realism" (1949-1956) [22, p. 12]. Certain restrictions were imposed on possible film topics. Filmmakers had to follow orders in choosing the theme and artistic manner of their films. The vocabulary of many cinematographers included the "scissors" notion denoting "the trimming of the artist's thoughts" [28, p. 37]. Furthermore, filmmakers were not given full-fledged prescriptions and rules on "how to shoot a movie" before their motion picture had been already produced.

The motion picture "Zakazane Piosenki" ("Forbidden Songs") [36] became the starting point for the production of feature films in Poland after World War II. "The production of feature films started with Leonard Buczkowski's "Zakazane Piosenki" (1947)" $[21$, p. 223]. This motion picture did not just symbolize the beginning of the "postwar Polish cinematography, it has been serving as a proof of strict censorship of war feature films for a long time" [26, p. 14].

The heroes of this motion picture are the songs of unconquered Warsaw. In fact, the whole film represents the sound of military songs playing against the wartime background, depicting the 
struggle of people from all the social classes: "guns are the power that brings death, and songs are the power of people's immortality" [37, p. 43]. The party commission on cinematography regarded this film as the embodiment of "system errors". "This film lacks the ideological connection... between its creators and cinematography leaders, on the one hand, and labor workers, on the other hand... The notions of "freedom" and "democracy" ... are represented as bourgeois self-will and liberalism" [23, p. 153]. The director showed the resistance of the Polish people to the enemy without distinguishing the patriotism and heroism of armed forces with different political ideologies - the Armia Ludowa, Armia Krajowa and Bataliony Chłopskie. Singing the same songs, the Poles in his motion picture act together.

Ford's motion picture "Ulica Graniczna" ("Border Street") [38] follows the tragedy of the Warsaw Ghetto Uprising of 1943. "It is a vivid film about the martyrology of Poland" [21, p. 223-224) The filmmakers managed to "reconstruct" the Warsaw Ghetto. "Thanks to the movie, this uprising went down in history as an example of heroism and martyrdom of Polish Jews... The movie is about protecting such high moral values as honor, dignity, humanism, courage and self-sacrifice in the fight against fascists" $[14, p$. 75]. Nevertheless, censorship authorities criticized the film since it represented insurgents of the Warsaw Ghetto as victims who should be sympathized but "the political situation in the country did not diminish the danger of many of them" [26, p. 25]. As a result, "new projects by A. Ford were rejected" [23, pp. 151-152]. Jakubowska's "Ostatni etap" ("The Last Stage") [34] holds a special place among the first postwar feature films. It won the Polish cinema international appreciation and brought the first festival awards. In 1950, the World Peace Council awarded the director the Peace Prize for the "anti-war character" of her motion picture $[29$, p. 10].

This film is a fine example of as a successful collaboration of Polish and foreign filmmakers, i.e. Jakubowska's co-screenwriter was a German, Gerda Schneider; the Soviet camera operator, Boris Monastyrskii, shot the film; the roles were played by actresses from different countries. In the wartime, many filmmakers were prisoners of the concentration camp in Auschwitz. The movie itself was shot in a concentration camp. The film reveals the everyday life of a female barrack and is made in a documentary manner: "Right after the war, we could not forget that pain, injustice and suffering. While working on our movie, we told about the things we saw and went through" [39, p. 72].

In the early $1950 \mathrm{~s}$, the war started to be perceived as a past event, and more peaceful topics were gradually introduced to the Polish cinema. Filmmakers tried to evade the theme of war but it was still present in the background (the ruins of buildings, gaping windows, the instability of wrecked facades, the figures of homeless people, etc.).

In the mid-1950s, new films appeared where war was interpreted in a different way. One of these motion pictures is the movie of Ford and Wajda "Piątka z ulicy Barskiej" ("Five Boys from Barska Street") [40] based on the so-called "naive scenario" [21, p. 226].

The following Ford's phrase is hard to pass off: "The war has long since ended. Someone else is playing it, and these games often end in death. Maybe it is time for us to remind them how scary war is" [41, p. 54]. The film addresses the problem of juvenile crimes. The director's intention was to divide the movie into two parts. The first part shows the life of young men during the war years when they had to be strong to fight against the invaders. The second part of the film is devoted to the first postwar days when the same men were supposed to reveal other human qualities in the peacetime. The Cinematography Department of the National Council for Culture and Art harshly criticized the director. Ford recalled, "I was told that I should have shown not just the end of the war but the beginning of a new, completely different life.. Now I think they meant socialist life" [26, p. 32]. The authorities asked to make the following changes: to show the evolution of main heroes in the second part of the movie under the influence of socialist labor; the imperialist intelligence should become the force behind crimes. Wajda said, "We spent many hours thinking how to put these things into the movie without ruining the story. Then we came up with an idea. One of the boys told about his friend who tried to avenge his father (a soldier of the Armia Krajowa) and committed a crime" [42, p. 141].

The Polish resistance as a way of unifying people is represented in Rybkowski's film "Godziny nadziei" ("The Hours of Hope") [43] that shows the end of the war and great confusion of the main heroes vividly expressed on their faces (there are many scenes of silence and meditation in the movie).

Wajda's "Pokolenie" ("A Generation") [44] is a motion picture that summed up the development of Polish feature films in the first postwar decade. This film tells the story of one possible fate suffered during the occupation. Many cinematography researches notice an innovative character of this movie. "Wajda's generation represents "the first manifestation of new trends anticipating both political and cinematographic changes" [21, p. 290]; "it is the earliest film of a new trend" "expressing the changes experienced by the Polish cinema in detail..." [24, p. 140]; "it draws the line under the dominance of socialist realism in the Polish cinema" $[22$ p. 12]; "it shows the birth of the Polish Film School and attempts to escape the opposition of positive and negative dogmatic clichés, and create real-life characters" [45, p. 147]. The film is especially valuable since it defined the further development of war feature films in Poland.

The film clearly reveals the artistic concept of war formed in the first postwar decade. This motion picture informs about real wartime events and generalizes the idea of fascism, i.e. it is a threat, cruelty and barbarism. What further development of Polish war films did Wajda offer?

The director significantly reduced the number of heroic events and characters. "These changes helped better show the hero's motivation and emphasize the hero's psychology and experience rather than the proclaimed ideology" [46, p. 19]. The main hero of the movie is a teenager who becomes acquainted with war and love. However, the director did not distinguish any priority factor in the personality's formation. "I wanted to show in my film that love is a factor that largely determines the person's political behavior" $[47$, p. 25]. The movie demonstrates war as something unnatural and incompatible with the logic of life. All moral and material values become vulnerable and fragile in the face of war. Wajda introduced a moral-value approach to his heroes believing that patriotism was not an inborn quality but a testament to the high level of personal development.

Other aspects of the film received much more criticism. The main heroes are members of the resistance movement of the Armia Ludowa. They reveal their true nature through ordinary and everyday activities. Wajda did not use any demonstrations or beautiful performances as a means of characterizing his heroes. There is only one episode in the film when the heroes utter the following oath: "I, the son of the Polish people, anti-fascist, swear courageously and to my last breath fight for the freedom of my people". While describing the actions of his heroes, the director did not lead them to some major event or scene. "Wajda gave up on the concept of action-like motion pictures" [24, p. 146]. In his "Generation", Wajda presented a bold interpretation of characters arguing with the notion of an "ideal hero": "An intelligent proletarian has already substituted real-life heroes on the screen. It is more like an obedient humanoid creature... Normal human characters were put in specific social and historical conditions" [20, p. 38]. Looking at the film characters, the viewer cannot decide which of them is a protagonist and who is an antagonist. The motion picture revives a ghetto uprising. Its protagonist initially refuses to join an operation to save the rebels, then, feeling guilty, he agrees and consequently dies. Wajda's heroes are individuals. Before this movie, any form of "uniqueness" had not been welcome in the Polish postwar cinema. It was still unwelcome a few decades later: "The film signalizes the emergence of dangerous trends" [48, $\mathrm{p}$. 143]. 
In 1956, the Polish cinema and spiritual life found a new hope associated with the process of renewal, development of creative freedom and censorship restriction. The natural course of time pulled people away from war events. The postwar development of Poland characterized by a large number of problems made filmmakers focus on contemporary social themes. It may seem that the Polish people of the second half of the 1950s and 1960s did not have any wartime memories but were worried about their current lives.

While analyzing the films of that period, one can notice that filmmakers addressed the current problems of society but still paid much attention to the theme of war. Young directors wanted to show their vision of war. One of the reasons for the filmmaker's constant attention to this topic was changes in the political and social life of Poland.

The premonition of coming changes and their anticipation had been noted by creative communities before 1956: "The creative intelligentsia at the turn of 1955-1956 ceased listening to orders" [16, p. 384]. In December 1955, an ideological meeting was organized at the party-state level. Jakubowska took part in the meeting and recalled, "There I saw many people who spoiled my films, they approached me and spoke positively about my work. I thought it was no accident. At first, I was surprised that I was invited at all, it had never happened before... The meeting did not change anything but at least they listened to us" [26, p. 73]. In March 1956, Ford was invited to the session of the Council for Culture and Art: "When they described my film "Five Boys from Barska Street" as a vivid motion picture about war, the people sitting in the front rows who "cut it in pieces", I did not even see their faces, nodded. I felt bitter at the fact that my film was not seen as it was supposed to be" [26, p. 75]. These meetings did not change anything but their organization showed that the authorities tried to restructure relations with cultural figures and reform political guidelines in the spiritual sphere. When filmmakers addressed the topic of war again in this period, they wanted to express previously forbidden aspects.

One should not assume that after 1956 creative freedom was resurrected in Poland. The Polish society and press criticizing the past pointed out the necessity of its rethinking. The war still concealed many secrets and altered facts.

In the mid-1950s, Polish war feature films underwent significant changes, i.e. war was interpreted in different ways and manifested itself in a variety of plot lines; filmmakers developed their own distinct style. The evolution of the Polish cinema between 1956 and the 1960s is clearly demonstrated in the motion pictures of Andrzej Wajda and Andrzej Munch - the central theme in war feature films was the so-called "Wajda-Munch anti-mythology" [30, p. 67].

In 1957, Wajda released the film "Kanay" ("The Sewer") [49] which laid the foundation of the Polish Film School and further cinematographic searches of war-related topics. War remained the main subject of many Polish films. The first minutes of the film show gaping holes, rubble, a crucifix turned upside down, piles of broken stones, descent into the underworld of the city drainage, walls of the Warsaw Ghetto and a desecrated Jewish cemetery. The director recalls the tragic Warsaw Uprising of 1944. After October 1956, "the Stalinist interpretation and propagandist vulgarization of the Polish history were thrown back. That is when the first monographs about the uprising were published" $[14, p$. 65]. Through his cinematographic efforts, Wajda also tried to tell the truth about the event. The film formed a new direction in the Polish cinema. Wajda did not question the reasonability of heroism or doubt the importance of the Warsaw Uprising as a whole: "It was the first time someone actualizes a problem of the Warsaw Uprising of 1944 that was provocatively hushed up in the previous decade. The director was well aware that families and friends of the uprising victims would demand reverence to the heroism of their loved ones. Andrzej Wajda paid tribute to the uprising that cost the city a million of lives. However, he honored the dead in a peculiar way showing the decline of the rebels driven into the stench and darkness of the city drainage. Using two tragic love stories, he expressed his amazement about ideological opponents disappointed, tormented by fear and bitterness but still fighting to the end" [21, p. 290]. If "A Generation" is characterized by clarity and certainty, the heroes of "The Sewer" are filled with bitterness, a sense of defeat, broken illusions and the meaninglessness of a heroic death" $[50$, p. 9]. The director made an interesting remark about these two motion pictures, "While still working on "A Generation", I planned my next film... I immediately realized that they would not let me shoot a movie about members of the Armia Krajowa... So, I decided to postpone this idea, especially since I did not have a script" [46, p. 18]. "The Sewer" is a long-planned and finally realized story revealing the other face of the Resistance.

Wajda did not idealize his characters. He did not just retell reallife events but rather described the personal lives of people: "This film is not a historical fresco but experiences of a particular group of people. It is the only way to evaluate and analyze the motion picture in accordance with the director's intentions" [42, p. 19]. This close attention to the fate of heroes is both Wajda's artistic manner and the peculiarity of that time when fictional figures ceased to be presented in a "schematic" and typical way.

The approval of "The Sewer" went more smoothly than that of "A Generation". Different opinions can be explained by the heterogeneity of the Polish society which comprised supporters of a new way of life and people who were afraid of any changes. Here are two opinions about Wajda's film. The opinion of the writer Maria Dombrovskaya was as follows [51, p. 115]: "I have lived for many years on this planet but I have not seen anything more shocking than this recent film. I think the film is very timely. Now, it seems that we are wandering the same canals in the peacetime and are afraid of bumping into a grate". Wajda's response to the writer was also of great interest [42, p. 145]: "When I was thinking about making this film, I wanted to tell about a particular event but then I thought that a grate at one of the exits from the city drainage symbolizes our life. Its bars are parted but they still exist". There is another opinion mentioned in the director's diary: "I was contacted by a Borkevich... The author of the letter sent me a long list of inaccuracies which he found in my film and asked me, "Does it bother you that most people will watch your film about the uprising rather than read the corresponding scientific papers?" I answered shortly, "No, I had to make this movie because not everyone will read such a book" [42, p. 145].

Wajda's next war feature film is called "Popiól i diament" ("Ashes and Diamonds") [52]. It is a screen adaptation of Jerzy Andrzejewski's eponymous novel, whose title refers to Cyprian Norwid's epigraph. However, the film recreates only one storyline of the original novel: the fate of Matzek Helmitsky and one special event (several hours of May 8, 1945) that symbolizes the end of the war, the whole historical era, and the beginning of radical changes. The film protagonist, a soldier of the Armia Krajowa, kills the communist, Shchuka, carrying out the task at the cost of his life and realizing the senselessness of this action. Wajda was often reproached for "some cruel scenes" [53, p. 29], but the brutality of a picturesque film episode was caused by the brutality of real events. The story about the wartime generation is a verdict that cannot be appealed, it is handed down by history and marks the beginning of a new social epoch: "Shot by a patrol, Matzek died in grievous agony in a city dump. He died not just as a soldier of the Armia Krajowa. It was the death of the whole system of opposing views. A beautiful but alien to a new life legend passes away" [30, p. 47].

Wajda's films (“A Generation", "The Sewer", "Ashes and Diamonds") are difficult to separate from each other since they depict the wartime generation and form a "drama in three acts", "a trilogy about the war" [50, p. 9]. "Ashes and Diamonds" tells the story about the wartime generation stepping into the postwar life. The war shown on the screen is no longer a panorama of major battles or heroic actions; it is regarded as an inseparable page of any person's life. While following the fate of Matzek, Wajda showed the war from an unusual perspective. Instead of reintroducing well- 
known historical events, he decided to depict a conditional fact, i.e. a doubting and complex character instead of a typical, "ideal" hero. The author of this article focuses on the film details. In the scene when Matzek assassinates the party secretary, the latter falls into his embrace. How to explain this performance? Płażewski believes [21, p. 292], "The director stresses... a thread of agreement between these two antagonists in the future that unites their concern about the country".

Why does Matzek wear modern clothes (narrow pants, sunglasses)? Płażewski replies [21, p. 293], "This Matzek looked like a Zempovets (Związek Młodzieży Polskiej - Union of the Polish Youth, a legal postwar youth organization) from the generation that will come only a decade later". The film showed the youth that "the absence of indifference to common affairs can always be a bridge leading to the future". The director made the hero more understandable to the young viewer and drew the attention of the latter to the current events happening in the country. Wajda did not impose certain ideas but encourage the youth to have their own opinion and defense it.

The audience received the film with enthusiasm. According to the survey (conducted by the newspaper "Życie Warszawy", July 1956), Wajda's "The Sewer", "Ashes and Diamonds" and Munch's "Eroica" were chosen as the most popular films [16, p. 444].

Based on E. Slavinsky's script, A. Munch's “antifascist motion picture" "Eroica" [54] is called in Italian and explained by the following subtitle: "A Heroic Symphony in Two Parts" [24, p. 148]. Płażewski [21, pp. 291-292] notes that the director was often reproached for ridiculing heroism and defaming insurgents. Wounded by such accusations, the director said in his interview, "Only a scoundrel can oppose heroism. Those who accuse me of representing anti-heroic tendencies in my films, greatly offend me. "Eroica" does not judge its characters even if their actions are irrational. All the characters are always shown with sympathy and heart". Relying on the authoritative interpretation of the antifascist representation in the Polish cinema, the researcher Andrzej Werner did not pay this film enough attention since Munch's reflections were too generalized. The director tells about an individual in a dangerous situation, addresses the problems of one's personality and the whole people's destiny, highlights the connection between people and history, considers the nature of heroism and roots of patriotism [21, p. 295].

Opposite assessments of the film demonstrate two approaches to understanding the concept of war. The Polish cinematographer had to choose one of them. The first approach is to describe war as a real historical fact or event ("The Sewer"). The second approach is to interpret war as an extra-historical phenomenon or disaster ("Eroica").

In 1959, Wajda released his new film about a military duty, honor and dignity. "Lotna" [55] is based on Wojciech Żukrowski's novel and shows the rivalry of two cavalry officers for possessing the horse called Lotna against the background of the catastrophic events of September 1939. Wajda represented the conflict as an imaginative clash of two worlds: the romanticism of the past and the cruel soullessness of modern warfare. The motion picture debuted on the silver screen without any interference of the state.

Wajda's film "Samson" [56] is a screen adaptation of Kazimierz Brandys's novel about the tragedy of Italian Jews. Wajda was interested in the persecution of a person different from others and therefore sentenced to death: "The occupation shown in "Samson" serves only as a background. I am more interested in the problem of the person's persecution than occupation itself. The main thing is that people are sentenced to death for their "different" faces" [33, pp. 110-112]. The protagonist perceives the prison he is held in as the quietest place in his life. He does not feel lonely there because everyone around him is just the same. The fate death of the character is inevitable. One's unpredictable life is just a form of death. Wajda refuted the psychology of fear leading to disunity and the loss of collective values. This motive was relevant for the Polish people of those years because "any resident of occupied
Poland could find themselves in Samson. The only difference was the so-called dying hierarchy of national and social groups doomed to death, among which Jews were the first to die" [21, p. 295].

While shooting the film "Pasażerka" ("The Passenger") [57], Munch acted as the successor of Jakubowska's ideas in depicting Nazi death camps. The film is based on the story and script of Zofia Posmysz-Piasecka, a former prisoner of Auschwitz. Munch was unable to finish the film but the motion picture was edited by Witold Lesiewicz. He managed to tactfully weave the director's death into the film and warned that the movie was more like a sketch: "We do not intend to finish the story the creator did not have time to tell" [21, p. 293-294].

The film tells two stories. "The part relating to the present day consists of static frames connected by stingy comments and narrowed to a small screen. However, when the story moves to Auschwitz, the screen expands and the imagery becomes more dynamic and psychologically meaningful. Munch was not interested in studying the guilt complex of war criminals that had been thoroughly analyzed before. He tried to consider the morally disturbing relationship between the executioner and the victim. The film muffles physical terrors of concentration camps by using a calm background. The director focused on a sensual connection that arises between the conqueror and the conquered. The film justifies the actions of a German woman. Although she does not shun dirty work, she is shown at the state of a moral collapse. She desperately tries to create an alibi in confrontation with a prisoner who refuses to take a privileged position" [21, pp. 293-294]. Like other motion pictures created by the Polish Film School, Munch's films capture the evolution of views on the past. In "The Passenger", the fatalism of the postwar worldview is replaced with an optimistic statement about a strong and beautiful human spirit.

In addition to Wajda's and Munch's motion pictures, the Polish war feature films of this period included the following thematic groups: memory films ("The Last Day of Summer" [58], "All Soul's Day" [59], "The Dark River" [60], etc.), films praising moral responsibility ("Tonight a City Will Die" [61], "The First Day of Freedom" [62], etc.), "guerrilla" films (Jerzy Passendorfer's, Kazimierz Kutz's and Jan Morgenstern's motion pictures), films about operations conducted by the Polish Army ("Rowanberry" [63], "Shadow" [64], "Unknown" [65], etc.), warrelated comedies ("Where is General?" [66], "How I Unleashed World War II" [67], "Giuseppe in Warsaw" [68], etc.).

The author of the article aims to determine the general features of films in all thematic groups. In the 1950s and 1960s, the number of characters acting in war feature films was seriously limited. While depicting wartime events, cinematographers tried not only to tell the viewer about a certain fact but wanted to present a reallike protagonist. Simplified and tendentious heroes characterized the first postwar films. Characters relentlessly followed the path of duty; filmmakers did not always clearly show the hero's spiritual struggle or complex motives of their actions. "New" Polish motion pictures revealed the "complexity" of their characters [69, p. 111]. Movie characters were no longer archetypes (soldiers of the Armia Ludowa or Armia Krajowa, enemies, etc.) but real-like human beings. The films of the second half of 1950 and the $1960 \mathrm{~s}$ were represented by "psychological war dramas and lyrical wartime stories" $[24$, p. 153]. The mythology manifested in the motion pictures of this period was criticized due to the strict censorship of the first postwar decade. The reinterpretation of the hero's concept was one of the reasons for an easier approval of films and their compliance with censorship rules. It comes naturally that a person can make mistakes, doubt their actions instead of a fictional character who serves as the typical personification of some group of people.

Polish cinematographers revealed more than just military events in their war feature films. They regarded war as a special stage between the pre-war and postwar time. The expanding chronological framework of the film narrative reduced schematism and supported the analytical perception of war represented as an outline of the 
country's postwar development. The connection between military and postwar life is one of the reasons for the popularity of war feature films in the Polish Film School, which simultaneously demonstrate the past and the present.

The representation of war provided by the Polish Film School is characterized by conceptual variability and dynamism. However, the evolution of war feature films was still heavily influenced by censorship, the degree of censorship of war-related films could change. The years between 1956 and 1959 marked "the period of transition associated with a struggle for power", therefore "censorship did not fully control the cinema" [16, p. 384]. Comparing the above-mentioned period to the 1960 s, one would notice that the censorship of spiritual life was significantly lower.

In 1959, the situation in the cultural sphere took a turn for the worse. After extensive public discussions, the party's leadership determined that the Polish intelligentsia did not contribute to the creation of a positive image of the authorities. Thus, they introduced more severe censorship in the spiritual life, which was intended to be a judge in the struggle of various themes and assessments: "We must use all opportunities to bring all worthy artists to our side, link them with the party ideology" [15, p. 333]. It was the beginning of a new stage in the tightening of censorship. Several sub-commissions distinguished by thematic features were set up on the basis of the commission on cinematography. They aimed to thoroughly analyze all the films produced during that period. It seemed that these sub-commissions were acting quite democratically. Decisions were made collectively, filmmakers were often invited to their meetings but could actually ignore the invitation.

After the events of 1968, many cultural figures fled Poland. Some magazines harshly criticized the motion pictures of Jerzy Bossak, Aleksander Ford, Jerzy Kavalerovich, Andrzej Wajda, etc. Their films were accused of "futile positive qualities born of the existing ideology" and "cosmopolitan" tendencies. Such creative associations as "KADR", "Nike", "Plan", "Rytm", "Studio" and "Siren" were dissolved. Instead, new ones were created - "Krai", "Nike", "Plan", and "Vectors". Many war feature films "were suspended and not released to big screens, while others were shown only in closed Good Film Clubs" [16, p. 521].

The theme of war was still relevant in the cinema of the $1970 \mathrm{~s}$ The fictional representation of war revealed new views and opinions. Wajda's film "Krajobraz po bitwie" ("Landscape After the Battle") [70] (the screen adaptation of Tadeusz Borowski's novels) is similar to "Popiól i diament" ("Ashes and Diamonds"). Both films are devoted to the tragic collapse of worldviews and the search for new life values. "Landscape After the Battle" differs from the masterpiece of the Polish Film School with its wisdom and mature reflection, more historical views on the first postwar years, the problem of choice that the Polish people faced during that time [30, p. 69]. According to Miron Chernenko [47, p. 45], the hero of "Landscape After the Battle" is "a man raised from the ashes". He is the exact opposite of Matzek from "Ashes and Diamonds". Wajda's film narrates the events of the first postwar years. The movie characters talk about the war, constantly recall it and bring those bitter memories into their current lives.

The film "Landscape After the Battle" is filled with typical Wajda's allegory. The main storyline covers the relationship between a girl and a young man who met and fell in love just before the war. Wajda intertwined their lives after the war to show that this tragedy ruined their relationship. War does not have mercy on people or their feelings, it threatens love. The motion picture vividly represents restless landscapes and compared them to rocky times. An unpleasant and dark landscape is a means of revealing the atmosphere of a new period filled with everyday problems. There is a lot of rain, clouds and stormy skies in the movie. The heroes of the film who are afraid to discuss their relationship can easily talk about the weather. These conversations helped them better understand each other. While talking about their lives, they use words describing different states of nature, for example, stuffiness, when it is cloudy or unsettling like before a storm. The camera operator shows a stormy sky through a frame resembling bars. War is no longer the main theme of the movie narrative. It does not determine the location of filming but it is clearly present in people and affects their lives in the peacetime. Wajda places the wartime between the past (the pre-war years) and the future (the postwar period).

The director mentioned the current events happening in Poland in the final credits. The audience sees a train that brings former prisoners of a German concentration camp home. The names of actors are rolling against sleeping cars, while the names of camera operators and hand artists are shown with a freight train in the background. The inscription "Directed by Andrzej Wajda" appears over a carriage with a barred prison window [50, p. 15]. He presented the war as a prelude to a hard postwar life. As a result, Wajda's war film was often regarded as contemporary-oriented. In the mid-1970s, "problem-based" war films gave way to films about modern life and screen adaptations of classical literary works. Despite some thematic diversity in the Polish cinema, warrelated motion pictures remained important. A new generation of directors changed the concepts of the past times. The plurality of views enriched the number of problems addressed by war feature films.

Bohdan Poręba's "Hubal" ("Major Hubal") [71] and Andrzej Trzos-Rastawiecki's, "Gdziekolwiek jesteś panie prezydencie" ("Wherever You Are, Mr. President") [72] are fine examples of a fundamentally new approach to the theme of war.

Poręba also directed "Droga na zachód" ("Road to the West") [73] in conformity with artistic techniques and sacrificial-tragic motifs of the Polish Film School. In this case, the cinematographer went beyond the school traditions. Hubal is the name of Uhlan Major Dobzhansky who does not lay down his arms after the defeat of Poland in 1939. Despite its controversial nature, the film had an exceptional success with viewers. Z. Zaluski explained it in the following way: “...people missed the stories about heroes...” [74, p. 147].

Trzos-Rastawiecki's film “Gdziekolwiek jesteś panie prezydencie" ("Wherever You Are, Mr. President") tells about ambiguous and controversial S. Starzyński, the Mayor of Warsaw and "the soul of Warsaw's defense" [23, p. 316]. The director explained his appeal to the events of 1939 and the personality of Stefan Starzyński in a letter to Krzysztof Zanussi: "I wanted to try my hand at war feature films since the Polish cinema cannot exist without this genre. I have already known how hard it was to get a motion picture approved. That is why I decided to make a film about Starzyński. It seemed that this kind of story could not be rebellious" $[75$, p. 110]. The movie included footages "edited" to look like documentary films and chronicles shot in Warsaw in September 1939. The camera operator, Zygmunt Samosiuk, filmed fictional episodes concealing the difference between documentaries and location shooting. Thanks to these joined efforts, the film is often called "the masterpiece of documentary cinema" [30, p. 71]. A wide use of documentaries and "chronicle-like" stylization in war feature films are typical of many cinematographers of the 1970s [31, p. 14].

The Polish cinema of the 1970s was characterized by certain thematic diversity but most filmmakers were still highly interested in the theme of war. Jan Lomnicki made two war feature films. The Soviet-Polish film "Ocalic miasto" ("To Save the City") [76] follows the actions of Soviet troops in Krakow. This type of war films reconstructing a real fact had already gone down in the history of the Polish cinema. Filmmakers preferred representing the people who lived during the war. Lomnicki's motion picture depicted war in the same manner as the first postwar films, i.e. it used large panoramic shooting, showed the dynamics of military operations and represented a plenty of mass scenes. The war demonstrated by Lomnicki unites a large number of people: "I wanted to show the war as it was shown before when the war really followed a man's life" [77, p. 149].

The director's second war feature film "Akcja pod Arsenałem" ("Operation Arsenal") [78] carried out the tradition of "guerilla 
films" laid by Kavalerovich and Passendorfer. This motion picture tells the story of a man who is doomed to death but continues his selfless struggle. The predetermination of a tragedy and resistance to imminent death form the heroism of this man: "Today we are in desperate need of people who do not think about material things (we have many of those) but about the highest truth and virtue that turn a person into a hero. War is a time of heroes. In this respect, it is a beautiful time" [77, p. 149]. These Lomnicki's words explain why filmmakers addressed the theme of war in the following years. They tried to find the examples of moral height revealed during the wartime and compared them to the existing "morbid" moral state of society. War feature films actualized many problems of the Polish society and addressed the same ideas as other themed motion pictures.

The stories told in the films of the 1970s often described the complex lives of people who experienced many hardships of the occupation regime. The Soviet-Polish film "Pomni imya svoye" ("Remember Your Name") [79] follows real events and people imprisoned in a concentration camp. The filmmakers addressed a challenging problem -mother-son separation and the strength of maternal love - that is very difficult to transfer to the screen. The movie regards war as a force that kills people and breaks their lives.

In the 1970s, the theme of war was represented in the context of other traditional topics. Numerous problems existing in the Poland of that time distracted filmmakers from war-related stories, and war feature films developed alongside other movie genres. War was perceived as a trigger to crises. The filmmaker's growing attention to the theme of war was inspired by the political and social activity of the Polish intelligentsia that looked back into the past to find answers to many questions. Nevertheless, war feature films were losing their popularity and fell out of favor in the 1980s: "War-related experiences and problems associated with the Nazi occupation and the postwar struggle for power played a smaller role in the Polish literature and cinema. The postwar generation entered the picture since these Polish people lived the following socio-political and ethical-moral problems: October 1956, March 1968 and December 1970. This generation was very distrustful of the authorities governing the People's Republic of Poland and kept an eye on the Western models and needs" [21, p. 576].

At the beginning of the 1980s, the People's Republic of Poland was characterized by a deep economic, political and social crisis. Opposing sentiments grew stronger in the country. Due to the acuteness of the existing problems, war feature films had lost their dominating role but cinematographers still paid enough attention to the theme of war.

In Różewicz's "Rys" ("Lynx") [80], the main character, a young Roman Catholic priest, is involved in an unsafe and morally difficult situation of sheltering the Jewish family and condemning an agent provocateur by the Polish underground resistance group. Czesław Petelski and Ewa Petelska represented the left-wing guerrilla movement in "Bołdyn" ("Boldyn") [81]. A bold debut was Waldemar Dziki's film "Kartka z podróży" ("Postcard from a Journey") [82] where the director created a generalized image of Jews imprisoned in ghettos and prepared for all possible tortures. In the film "Kronika wypadków miłosnych" ("A Chronicle of Amorous Accidents") [83], Wajda showed the beginning of the war and two lovers who voluntarily accepted their death a few moments before the war so they would not see the arrival of big troubles. The motion picture consists of "two layers, the myth of Arcadia who lost her youth and the realistic reconstruction of the impending cataclysm, which is World War II" [50, p. 15].

The theme of war was gradually losing its importance in the cinema of the 1980s due to a number of reasons. War events inevitably remained in the past despite attempts of the Polish intelligentsia to keep them relevant. A new generation of directors promoted contemporary stories and created "competition" for experienced masters of war feature films. At the same time, censorship demanded the dominance of industrial films showing the heroism of labor and the propaganda of success. The 1980 s can be described as the aggravation of a psychological crisis when the state and society searched for a new development path, various political and ideological trends formed in the country, and people constantly doubted their choice. In response, directors expressed their opinion on possible ways out of the crisis.

The theme of war became irrelevant in the Polish literature, which also affected its cinema. In the 1980s, cinematographers made films about war events of the past centuries. In addition, the global audience grew more aware of the Polish culture. A high demand for various topics, overseas trips of Polish filmmakers, their artistic pursuits in other spheres (for example, theaters), the production of collective motion pictures, etc. - all these facts caused a gradual shift away from war-related themes.

\section{Discussion}

In this section of the article, the author interprets the research results based on the study of a wide range of documents and surveys, some of which are indicated in the first theoretical part.

The development of Poland in the second half of the 1940s and the late 1980s was a complex and contradictory process. While studying the history of the People's Republic of Poland, one should distinguish short-term, yet different stages, i.e. characteristics of the country's political and economic development, the content of economic, social and cultural policies of the authorities. The period between the second half of the 1940s and the first half of the $1950 \mathrm{~s}$ in the history of Poland is associated with the establishment of people power and Stalinism (the nationalization of industry, the collectivization of agriculture, the party's monopoly, the party's and state's control over the spiritual life of society, the establishment of close relations with the Soviet Union).

The period between 1956 and the 1960s in the country's development was marked by two severe socioeconomic and political crises of 1956 and 1970 . The country shaped a political course to improve its economy, strengthen cooperative stores, democratize socio-political life and regulate relations with the Soviet Union. The implementation of this course was characterized by several grave mistakes (the high-priority development of heavy industry at the expense of agriculture and social sphere, the use of extensive economic development, the restriction of workers' selfgovernment, the violation of voluntarism in the peasant's collective farming, the restriction of inner-party democracy, and the control of the spiritual life of society). In the late $1950 \mathrm{~s}$, the party deviated from the course proclaimed in October 1956 since it had led to the country's economic stagnation, limitation of the people's democracy in politics, and social instability. The country's development between 1956 and the 1960s resulted in a crisis that caused the consequent crises of 1968 and 1970.

The 1970s marked the next stage of the Polish history characterized by attempts to increase the country's economic development and form a well-developed socialist society. The development of Poland in this period was contradictory and inconsistent. However, there were certain successes (for instance, the growth of heavy industry, the establishment of economic relations not only with the Soviet Union but also with the West), unresolved problems had piled up, including the dependence of the national economy on external economic activities. In the mid-1970s, the country was again in a socioeconomic and political crisis. As a result, a broad opposition movement was formed consisting of all social classes but its base was laid by laborers who were not controlled by the authorities and official trade unions. Due to these processes, a new force entered the political arena in the late 1970s - an independent self-governing labor union called "Solidarność".

The development of Poland in the 1970s resulted in the crisis of the early 1980s that led to the introduction of martial law in the country. The 1980s became the last stage of the historical development of socialist Poland characterized by some elements of economic and political crises, the development of the opposition 
movement, the political confrontation and widespread criticism of the country's leaders. The state could not fully control the situation in Poland. There was a struggle between reformative and conservative forces. By the end of the 1980s, the Polish society had opted for new socio-economic, political and ideological relations due to a deteriorating economic situation, activities of reformative forces in society and changes in the Soviet Union. The country actually experienced a certain revolution. The adoption of the new Constitution of 1989 marked the beginning of a new stage in the development of Poland.

Closely connected and interdependent socio-economic and political processes represented the development of the spiritual life of Poland in the second half of the 1940s and the late 1980s. Characterizing the evolution of the spiritual life of the People's Republic of Poland, one should adhere to the periodization of its systemic development. In the second half of the 1940s and the first half of the 1950s, the authorities defined the country's development strategy in the sphere of education, science, culture and art.

The development of spiritual life was built over the principles of people's democracy. Representatives of the pre-war intelligentsia played an important role in the spiritual life of Poland. Strengthening the political position of socialist forces led to the intervention of Communists in social and cultural spheres. The views and ideas on the country's development strategy contradictory to the official ones were severely pursued. Great contradictions were noted in the relationship between the state and the Polish Roman Catholic church. The socialist state attempted to reduce the church influence on spiritual life.

Since 1956, the spiritual life of Poland had been experiencing new and optimistic changes. The Polish society held a wide discussion about the ways of further development, with the country's intelligentsia playing a significant role. Since the late 1950s, the course for the spiritual improvement of Poland had been gradually curtailing, which led to the renewed state intervention in public and cultural life. There were two directions in the development of the spiritual life in the country - official and illegal. Scholars firstly mentioned the phenomenon of "internal emigration", while some representatives of the Polish intelligentsia fled abroad. In the 1970s, the spiritual life of society, as well as its socio-economic and political spheres, experienced certain features of an upcoming crisis. The spiritual life in Poland was controlled by the state but the position of opposition forces became stronger in the late 1970s. The Polish Roman Catholic church was the only organization independent of the state and had an indisputable authority over Polish citizens.

The Polish spiritual life in the 1980s was characterized by a high social activity of its citizens, widespread criticism of the party's leadership attempts to eliminate the command and administrative system, the strengthening of anti-socialist sentiments, the development of relations with the West. In the late 1980s, the Polish society reached a new stage in the historical development of the country.

The evolution of the spiritual life of the Polish society in the second half of the 1940s and the late 1980s directly depended on the state cultural policy. The state policy was inconsistent and contradictory in this sphere of life just like in socio-economic and political ones. The nationalization of industry and consolidation of the party's positions turned the party into a trendsetter of artistic tastes in the country.

The state financed the development of culture and put forward certain conditions and requirements for artists. During the second half of the 1940s and the first half of the 1950s, the state started interfering in cultural life through strict censorship. Socialist realism had become the leading artistic method in the Polish culture for a long time.

Between 1956 and the 1960s, the state strictly controlled the development of culture. However, the first years of this period were marked by uplifted censorship and the development of creative freedom. Socialistic realism remained the leading artistic method encouraged by the authorities. There was a large network of vari- ous commissions exercising control over the people of culture and art. The main criterion for a highly artistic work was the conformity of the presented artistic image with socialist ideology. Many artworks created by gifted and innovative artists remained unknown, i.e. literary works were written "for the drawer" and films ended their days "on the shelf".

In the 1970s, the state policy in the field of culture did not change. The censorship carried out by various departments of the Ministry of Culture accountable to the party the Council for Culture and Art not only preserved the leading position of socialist realism but also started to interpret this method in a distorted manner. Due to the state policy called "Propaganda of Success", art could not represent life in a holistic and realistic way. A wide range of themes connected with the ideas of socialist realism was narrowed down to industrial and heroic scenarios. This censorship led to the development of illegal culture, whose popularity had significantly increased by the end of the 1970s.

In the 1980s, the state tried to keep its lid on the Polish culture. During the years of martial law, most cultural associations and societies were closed, and the state ceased financing many cultural projects. When martial law was abolished several changes took place in the cultural policy of the state, i.e. the state permitted the cooperation of cultural workers with representatives of the Western culture, non-state cultural projects and private commercial studios. The cultural life of Poland became more diverse. In the last years of socialist Poland, cultural policy was based on the principle of national harmony and cooperation of all movements that did not contradict the Constitution.

\section{Conclusion}

In the first postwar years, the Polish cinema was nationalized, and since then the state had been determining the development of filmmaking. Censorship played a big role in the production of motion pictures. Between the second half of the 1940s and the first half of the 1950s, special departments supervising the activity of filmmakers had been established. The entire process of creating a motion picture was subject to regulation, from writing a script to demonstrating a film on a big screen. The Congress of Filmmakers in Wisła led to total censorship of the Polish cinema. Between 1949 and 1955, the Polish cinema was dominated by socialist realism. The films of the first postwar decade greatly differed in terms of their intellectual and artistic values.

Initially, the Polish postwar cinema revolved around war feature films. This thematic dominant was determined during the wartime. Cinematographers drew the viewer's attention to the Warsaw Ghetto Uprising of 1943, the German occupation policy in Poland, the Polish resistance movement and the horrors of concentration camps. The war was reflected through the image of a "mass" opposing the enemy, whose heroes were idealized and typified. The development of war feature films was closely connected with documentary filmmaking and literature.

During the period between 1956 and the 1960s, the postwar Polish cinema finally formed its specificity. The Polish Film School of that time was characterized by the dominance of war feature films. The overall development of cinema was still determined by the state. The attempts to change the public life undertaken after 1956 enriched the thematic diversity of the Polish cinema. A wide range of motion pictures produced by Polish filmmakers was concerned with the postwar reality and its acute problems.

In the 1970s, the state was still controlling the Polish cinematography. This period was similar to the previous years when filmmakers paid much attention to various topics, including events of World War II, the lives of laborers and intellectual workers, the problems of children and young people, fideism, and the screen adaptation of classical literature. The state policy called "Propaganda of Success" gave priority to "industrial" films that were characterized by tendentiousness, oversimplification and suppression of many problems. A progressive trend in the cinema devel- 
opment was the introduction of the "cinema of moral anxiety", i.e. films concerned with various topics interpreted against the established norms. These films expressed the opposition ideas and ideologies manifested in the 1980s.

The martial law regime adversely affected the development of cinematography in Poland since cinemas were closed, the activity of Polish filmmakers was suspended and their work on many films was seriously hindered. When martial law was lifted, the life of cinema in Poland revived. Polish filmmakers aspired not only to move beyond well-established schemes but also tried renewing the society they were living in through their films. Many cinematographers supported opposition ideologies and joined Solidarność (Independent Self-governing Labour Union "Solidarity"). The motion pictures made in the 1980s brought up a variety of modern problems, critically interpreted the Polish history and its recent past. Back then, war feature films fully lost their dominant position. A new trend in the development of the Polish cinema was the opening of author's studios which created timely and topical films.

\section{References}

[1] Aronsen L. \& Kitchen M (1988), The Origins of the Cold War in Comparative Perspective: American, British and Canadian Relations with the Soviet Union. 1941-1948. N.Y.: St. Martin's Press.

[2] Bernhard MH (1974), The Origins of Democratization in Poland. New York: Columbia University Press.

[3] Ciechanowski J, The Warsaw Rising of 1944. Cambridge: Cambridge University Press, 1974.

[4] Feibleman JK (1998), The Theory of Human Culture. N.Y: Duell.

[5] Fish S (1998), The Determinants of Economic Reform in the PostCommunist World East. European Politics and Society 12, 31-78.

[6] Friszke A (1994), Opozycja polityczna w PRL. 1945-1980. Londyn: ANEKS.

[7] Michnik A (1984), Szanse polskiej demokracji. Londyn: ANEKS

[8] Poklewski J (2000), Art in the Service of Stalinist Propaganda. Czasy Nowozytne. Toruñ 1, 127-137.

[9] Raina P (1978), Political Opposition in Poland. 1954-1977. London: Poets' and Painters' Press.

[10] Serczyk J (2000), Reminiscences of Polish Universities in the Stalinist Era. Czasy Nowoiytne. Toruñ 1, 65-84.

[11] Starski S (1982), Class Struggle in Classless Poland. Brooklyn, NY: South End Press.

[12] Szymanski A (1984), Class Struggle in Socialist Poland: With Comparisons to Yugoslavia. Santa Barbara, California: Praeger.

[13] Waszak L (1996), Agreement in Principle: Wartime Partnership of General Wladyslaw Sikorski and Winston Churchill. N.Y.: P. Lang.

[14] Bronislavsky E \& Vachnadze G (1990), Polskii dialog. Sobytiya v Polshe glazami polskikh, sovetskikh, amerikanskikh, angliiskikh, zapadnogermanskikh $i$ frantsuzskikh zhurnalistov [The Polish dialogue. Events in Poland as seen by Polish, Soviet, US, English, West German and French journalists]. Tbilisi: Ganatleba.

[15] Dybkovskaya A, Zharyn M \& Zharyn Ya (1995), Istoriya Polshi s drevneishikh vremen do nashikh dnei [The history of Poland from ancient times to the present day]. Warsaw: Nauchnoe izdatelstvo "PVN".

[16] Czubinski A (1990), Polska I Polacypo II wojnieświatowej (19451989). Polska. Dziejenarodu, państwaikultury. Pod red. J. Topolskiego. T.VI. Poznań: Wydaw. inst. Zachodniego w Poznaniu.

[17] Rakulski J (1990), Poland: ideology, legitimacy and political domination. Dominant ideologies. London.

[18] Lotman YuM (2005), Semiotika kino i problemy estetiki. Ob iskusstve [The semiotics of cinema and aesthetic problems. About art]. Saint Petersburg: Iskusstvo, 288-372.

[19] MacDonald K (2018), Teoriya filmov [The theory of films]. Kharkov: Gumanitarnyi tsentr.

[20] Teplits E (1974), Istoriya kinoiskusstva [The history of cinematography]. 1939-1945. Moscow: Progress.

[21] Płazewski I (2001), Historia filmu. 1895 - 2000. Warszawa.

[22] Zwierchowski P (2000), Zapomniani bohaterowie: o bohaterach filmowych polskiego socrealizmu. Warszawa: Wydawn. Trio, 2000.

[23] Madej A (2002), Kino, władza, publiczność: kinematografia polska w latach 1944-1949. Bielsko-Biała: Prasa Beskidzka.

[24] Rubanova I (1980), Bitvy za mir - surovy. [Fighting for peace is severe] Iskusstvo kino 5, 136-156.
[25] Rubanova I (1989), Chto Polsha? Chto kino? [What is Poland? What is cinema?] Iskusstvo kino 1, 129-138, 2, 154-163.

[26] Molchanov VS (1989), Filmy sotsialisticheskoi Polshi: sozdanie, sudby [Films of socialistic Poland: their creation and fate]. Moscow.

[27] Kratkaya istoriya Polshi: $S$ drevneishikh vremen do nashikh dnei [The brief history of Poland: from ancient times to the present day]. Moscow: Nauka, 1993.

[28] Yurenev RN (1997), Kratkaya istoriya kinoiskusstva [Brief history of cinematographic art]. Moscow: Izdatelskii tsentr "Akademiya".

[29] Sobolev RP (1967), Vstrecha s polskim kino [Meeting with the Polish cinema]. Moscow: Byuro propagandy sovetskogo kinoiskusstva.

[30] Sobolev RP (1979), Puti polskogo kino. Kino nashikh druzei [Landmarks of the Polish cinema. Films of our friends]. Moscow: Znanie.

[31] Sumenov NM (1982), Iskusstvo, sozdannoe druzyami [Art created by friends]. Moscow: Znanie.

[32] Mihalkovich VI (1978), Stil' kinematografa i stil' fil'ma [Cinema style and film style]. Iskusstvo kino, 1, 199.

[33] Yurenev RN (1961), Kino za rubezhom [Foreign cinema]. Moscow: Znanie.

[34] Jakubowska W (1948), Ostatni etap [The Last Stage] [feature film]. Poland: Przedsiebiorstwo Państwowe Film Polski.

[35] Shatova EN (2015), Polskoe kino pervykh poslevoennykh let (1944-1956): vliyanie tsenzury na sudbu i soderzhanie kinoteksta [The Polish cinema of the first postwar years (1944-1956): the influence of censorship on the fate and essence of a cinemagraphic text]. Vestnik Leningradskogo gosudarstvennogo universiteta imeni A.A. Pushkina 4, 272-282.

[36] Buczkowski L (1946), Zakazane piosenki [Forbidden Songs] [feature film]. Poland: "Film Polski".

[37] Kavalerovich E (1990), Razmyshleniya [Reflections]. Ekho planet 2, 42-44.

[38] Ford A (1948), Ulica Graniczna [Border Street] [feature film]. Poland: Film Polski (Łódź).

[39] Kamshalov A \& Nesterov V (1975), Srazhayushchiisya ekran. Tema antifashizma v mirovom kinematografe [Fighting screen. Antifascism in the world cinema]. Kommunist 12, 69-77.

[40] Ford A (1953), Piątka z ulicy Barskiej [Five Boys from Barska Street] [feature film]. Poland: Film Polski (Łódź).

[41] Karaganov A (1969), Kinematograficheskie vstrechi [Cinematographic encounters]. Moscow: Iskusstvo.

[42] Wajda A (1989). Dnevnik rezhissera [The director's diary]. Iskusstvo kino 1, 139-147.

[43] Rybkowski J (1955), Godziny nadziei [The Hours of Hope] [feature film]. Poland: Wytwórnia Filmów Fabularrnych w Łodzi.

[44] Wajda A (1954), Pokolenie [A Generation] [feature film]. Poland: KADR.

[45] Lavrentiev S (1988). Tugie uzly [Tight knots]. Iskusstvo kino 6, 143-152.

[46] Wajda A (1990), Moi zapiski ob iskusstve [My notes on art]. Tvorchestvo $1,17-21$.

[47] Chernenko MM (1985), Andrzej Wajda. Moscow: Iskusstvo.

[48] Lavrentiev S (1988), Fenomen stalinizma v kinematografe sotsialisticheskikh stran [The phenomenon of Stalinism in the cinema of socialistic countries]. Iskusstvo kino 6, 143-152.

[49] Wajda A (1957), Kanat [Sewer] [feature film]. Poland: KADR.

[50] Zorkaya N (2000), Andrzej Wajda - syn Polshi [Andrzej Wajda the son of Poland]. Nezavisimaya gazeta.

[51] Dombrovskaya M (1978), Pisma [Letters]. Inostrannaya literatura 2, 115-123.

[52] Wajda A (1958), Popiól i Diament [Ashes and Diamonds] [feature film]. Poland: KADR.

[53] Stykalin AS (2002), Sovetskaya kultura v vospriyatii tsentralnoevropeiskoi intelligentsii (vtoraya polovina 1940-kh godov) [The Soviet culture as seen by the intelligentsia of Central Europe (the second half of the 1940s)]. Slavyanovedenie 3, 13-22.

[54] Munch A (1958), Eroica [feature film]. Poland: KADR.

[55] Wajda A (1959), Lotna [feature film]. Poland: KADR.

[56] Wajda A (1961), Samson [feature film]. Poland: KADR.

[57] Munch A (1961-1963), Pasażerka [Passenger] [feature film]. Poland: Zespół Filmowy "Kamera".

[58] Konwicki T (1958), Ostatni dzień lata [The Last Day of Summer] [feature film]. Poland: KADR.

[59] Konwicki T (Director), Zaduszki [All Souls' Day] [feature film]. Poland: KADR, 1961.

[60] Szyszko S (1973). Ciemna rzeka [Dark River] [feature film]. Poland: Iluzjon. 
[61] Rybkowski J (1961). Dziś w nocy umrze miasto [Tonight a City Will Die] [feature film]. Poland: Zespół Filmowy Rytm.

[62] Ford A (1965), Pierwszy dzień wolności [The First Day of Freedom] [feature film]. Poland: Zespół Filmowy Studio.

[63] Petelska E \& Petelski C (1969), Jarzebina czerwona [Rowanberry] [feature film]. Poland: Iluzjon.

[64] Kawalerowicz J (1956), Cień [Shadow] [feature film]. Poland: WFF Wroclaw, ZRF.

[65] Lesnevich W (1966), Nieznany [Unknown] [feature film]. Poland: Przedsiebiorstwo Państwowe Film Polski.

[66] Chmielewski T (1963), Gdzie jest general... [Where is General?] [feature film]. Poland: Zespół Filmowy "Start".

[67] Chmielewski T (1970), Jak rozpetatem druga wojne światowa [How I Unleashed World War II] [feature film]. Poland: Przedsiebiorstwo Realizacji Filmów "Zespoły Filmowe".

[68] Lenartowicz S (1964), Giuseppe $w$ Warszawie [Giuseppe in Warsaw] [feature film]. Poland: KADR.

[69] Golovskoi V (1976), Temnaya reka [Dark river]. Na ekranakh mira 6.

[70] Wajda A (1970), Krajobraz po bitwie [Landscape After the Battle] [feature film]. Poland: "X" Film Studio.

[71] Poręba B (1973). Hubal [Major Hubal] [feature film]. Poland: Zespół Filmowy Panorama.

[72] Trzos-Rastawiecki A (1978), ...Gdziekolwiek jesteś panie prezydencie... [Wherever You Are, Mr. President] [feature film]. Poland: Studio Filmowe Tor.

[73] Poręba B (1961), Droga na zachód [Road to the West] [feature film]. Poland: Zespół Realizatorów Filmowych „Kamera”.

[74] Zaluskii Z (1967), Propusk v istoriyu [History pass]. Moscow: Progress.

[75] Besedy s Kshishtofom Zanussi [Conversations with Krzysztof Zanussi] (1993). Iskusstvo kino 6, 109-117.

[76] Łomnicki J (1976), Ocalic miasto [To Save the City] [feature film]. Poland: KADR, MOSFILM.

[77] Lomnicki J (1989), Pocherk [Signature]. Iskusstvo kino 1, 148-153.

[78] Lomnicki J (1978), Akcja pod Arsenatem [Operation Arsenal] [feature film]. Poland: Iluzjon.

[79] Kolosov S (1974), Pomni imya svoye [Remember Your Name] [feature film]. USSR, Poland: Mosfilm, Illusion.

[80] Różewicz S (1981), Rys [Lynx] [feature film]. Poland: Zespół Filmowy Tor.

[81] Petelska E \& Petelski C (1981), Bołdyn [Boldyn] [feature film]. Poland: Iluzjon.

[82] Dziki W (1983), Kartka z podróży [Postcard from a Journey] [feature film]. Poland: Studio Filmowe im. Karola Irzykowskiego.

[83] Wajda A (1986). Kronika wypadków miłosnych [A Chronicle of Amorous Accidents] [feature film]. Poland: Perspektywa. 